\title{
U-Pb Zircon Dating of Ash Fall Deposits from the Paleozoic Paraná Basin of Brazil and Uruguay: A Reevaluation of the Stratigraphic Correlations
}

\author{
A. C. Rocha-Campos, ${ }^{1}$ M. A. S. Basei, ${ }^{1}$ A. P. Nutman, ${ }^{2}$ P. R. Santos, ${ }^{1}$ C. R. Passarelli, ${ }^{1, \star}$ \\ F. M. Canile, ${ }^{1}$ O. C. R. Rosa, ${ }^{1}$ M. T. Fernandes, ${ }^{1}$ H. Santa Ana, ${ }^{3}$ and G. Veroslavsky ${ }^{4}$ \\ 1. Instituto de Geociências, Universidade de São Paulo, São Paulo, Brazil; 2. GeoQuEST Research Centre, School \\ of Earth and Environmental Sciences, University of Wollongong, Wollongong, New South Wales, 2522, \\ Australia; Research School of Earth Sciences, Australian National University, Canberra, Australian \\ Capital Territory, 2000, Australia; and Institute of Geology, Chinese Academy of Geological \\ Sciences, 26 Baiwanzhuang Road, Beijing 100037, China; 3. Administración Nacional \\ de Combustibles, Alcohol y Petróleo, Montevideo, Uruguay; 4. Facultad de \\ Ciencias, Universidad de la República, Montevideo, Uruguay
}

\begin{abstract}
A B S T R A C T
Ash fall layers and vitroclastic-carrying sediments distributed throughout the entire Permian stratigraphic range of the Paraná Basin (Brazil and Uruguay) occur in the Tubarão Supergroup (Rio Bonito Formation) and the Passa Dois Group (Irati, Estrada Nova/Teresina, Corumbataí, and Rio do Rasto Formations), which constitute the Gondwana 1 Supersequence. U-Pb zircon ages, acquired by SHRIMP and isotope-dissolution thermal ionization mass spectrometer (IDTIMS) from tuffs within the Mangrullo and Yaguari Formations of Uruguay, are compatible with a correlation with the Irati and parts of the Teresina and Rio do Rasto Formations, respectively, of Brazil. U-Pb zircon ages suggest maximum depositional ages for the samples: (1) Rio Bonito Formation: ages ranging from 295.8 \pm 3.1 to $304.0 \pm 5.6 \mathrm{Ma}$ (Asselian, lowermost Permian), consistent with the age range of the Protohaploxypinus goraiensis subzone; (2) Irati Formation: ages ranging from $279.9 \pm 4.8$ to $280.0 \pm 3.0 \mathrm{Ma}$ (Artinskian, middle Permian), consistent with the occurrence of species of the Lueckisporites virkkiae zone; (3) Rio do Rasto Formation: ages ranging from $266.7 \pm 5.4$ to $274.6 \pm 6.3 \mathrm{Ma}$ (Wordian to Roadian, middle Permian). All the SHRIMP U-Pb zircon ages are consistent with their superimposition order in the stratigraphy, the latest revisions to the Permian timescale (International Commission of Stratigraphy, 2018 version), and the most recent appraisals of biostratigraphic data. The ID-TIMS U-Pb zircon ages from the Corumbataí Formation suggest that $\mathrm{U}-\mathrm{Pb}$ ages may be $>10 \%$ younger than interpreted biostratigraphic ages.
\end{abstract}

Online enhancements: appendix tables.

\section{Introduction}

We present here 11 SHRIMP and one isotopedissolution thermal ionization mass spectrometer [ID-TIMS] U-Pb zircon age determinations on 10 ash fall deposits and volcanic particles dispersed in Permo-Carboniferous strata in the Paraná Basin in Brazil and Uruguay (fig. 1; table A1; tables A1 and A2 are available online). In addition, detrital zircon age data are presented from underlying Carbonif-

Manuscript received March 29, 2018; accepted October 16, 2018; electronically published February 4, 2019.

* Author for correspondence; email: cr.passarelli@usp.br. erous sedimentary layers, in which volcanic input was not found. Tuff ages can provide independent age estimates to evaluate biostratigraphic ages. Results are discussed in the light of the stratigraphic ordering of the layers and their suggested paleontological ages.

Considerable volcanic ash reached the Paraná Basin during the late Paleozoic (Coutinho et al. 1991; Coutinho and Hachiro 2005; Rocha-Campos et al. 2011). Volcanic deposits may be sourced from repeated lower to middle Permian (and perhaps latest Carboniferous) plinian to ultraplinian eruptions from volcanoes 2000-2500 km away, in the Choiyoi Ig-

[The Journal of Geology, 2019 volume 127, p. 167-182] (C) 2019 by The University of Chicago. All rights reserved. 0022-1376/2019/12702-0003\$15.00. DOI: 10.1086/701254 
neous Province of northwestern Argentina (RochaCampos et al. 2011 and references therein). Volcanic ash was deposited and preserved across southern Gondwana in both marine and terrestrial environments (see Rocha-Campos et al. 2011).

\section{Paraná Basin}

Regional Geology and Stratigraphy. The Paraná Basin covers an area of around 1.4 million $\mathrm{km}^{2}$ (Milani et al. 2007; Holz et al. 2010), with most of it (1.1 million $\mathrm{km}^{2}$ ) in Brazil (fig. 1), and contains $>3000 \mathrm{~m}$ of late Paleozoic strata. The basin is a sagtype intracratonic depression developed on the South American platform (Almeida 1980). The synthesis of the main features of the basin is presented in figure 1, adapted from Milani et al. (2007). It is a roughly elliptical area with marginal deformations represented by several tectonic arches (e.g., Ponta Grossa, Rio Grande Arch, and Asunción Arch). The concentric distribution of the successive supersequences is depicted, as well as the sampling points utilized in this article. A comparison of the currently accepted chronology of the late Paleozoic strata and the ages resulting from our research are also shown.

The late Paleozoic strata comprise the thickest sedimentary pile preserved in the basin (fig. 1). Most of the stratigraphic nomenclature currently in use was pioneered by David White (1908) and later modified by Mackenzie Gordon Jr. (1947). Besides superposition, the initial chronostratigraphy was based on paleontology. Later, new subdivisions were created on the basis of surface (Schneider et al. 1974) and subsurface (França 1994) mapping, but their use remains difficult.

Depositional History. The late Paleozoic Paraná Basin succession rests unconformably on Precambrian and Devonian basement (Milani et al. 1994). The chief stratigraphic division of the basin is into the upper Carboniferous to lower Permian Tubarão Supergroup and the middle to upper Permian Passa Dois Group (e.g., Holz et al. 2010; fig. 2). Rocks are predominantly siliciclastic, but mudstones, carbonates, and economically important coals and oil shales are also present (Castro 1988). Importantly, there are ash fall layers that punctuate much of the stratigraphic interval (Coutinho et al. 1991; Coutinho and Hachiro 2005; Rocha-Campos et al. 2011). U-Pb dating of volcanogenic zircons offers an opportunity to estimate stratigraphic depositional ages to provide a tool for age correlation. The succession is punctuated by depositional hiatuses, some erosional breaks, and also lateral interfingering of different sedimentary facies. This makes correlation of units throughout the vast basin difficult.
The late Paleozoic depositional history of the Paraná Basin starts with the widespread occurrence of glaciogenic rocks, mainly of glacial-marine facies, in the Itararé Group (lower part of the Tubarão Supergroup), reflecting an icehouse period, probably of a few tens of millions of years, during the Gondwana ice age (Martin 1961; Rocha-Campos 1967; Frakes and Crowell 1969; Santos et al. 1996; Crowell 1999; Rocha-Campos et al. 2008). Glaciation spread from a center in the Namibian highlands, reaching westward as far as the eastern margin of the Paraná Basin (Martin 1961; Rocha-Campos 1967; Frakes and Crowell 1969; Santos et al. 1996; RochaCampos et al. 2008). On the western margin, glacial flow has been interpreted to be east directed (Frakes and Crowell 1969; Farjallat 1970) or northwest directed (Gesicki et al. 2002). Currently, there are few, if any, reliable radiometric age determinations on this glaciation event in South America. The maximum thickness of the Itararé Group is $200-600 \mathrm{~m}$ in outcrop and $1400 \mathrm{~m}$ in subsurface (França 1994). Its upper contact with the overlying Rio Bonito Formation at the base of the Guatá Group (upper Tubarão Supergroup) is locally erosive to sharp or transitional (Holz et al. 2010).

The postglacial late Carboniferous and possibly early Permian marine transgression (Rio Bonito Formation, Guatá Group) was marked by deposition of silty shales and carbonate-bearing rocks. This was followed by a Permian regression that culminated in widespread deposition of fluviatile, lacustrine, and aeolian sedimentary rocks, punctuated by restricted basin marine transgressions under conditions of increasing aridity (Zalán et al. 1991; Milani et al. 2007; fig. 2).

The boundary between formations is in most cases transitional to sharp and only locally disconformable. However, there are several important gaps within the stratigraphy, markedly at the base of the Rio Bonito Formation, near the start of the Permian, and in the upper Permian beds above the Rio do Rasto Formation (fig. 2). Some nonmarine environments were inhabited by the Glossopteris-Gangamopteris flora (Rösler 1978; Bernardes-de-Oliveira et al. 2005, 2016; Mune and Bernardes-de-Oliveira 2007), from which the economically significant coal beds in the Rio Bonito Formation were generated.

However, several crucial questions remain unresolved in understanding the late Paleozoic stratigraphy of Paraná Basin. The first-order ones are the duration of the Gondwana I Supersequence, the ages of the disconformities within it, and linking the absolute chronology with the observed major changes in biota (e.g., Fabris de Matos et al. 2001; Santos et al. 2006; Milani et al. 2007; Souza et al. 2007; Guerra-Sommer et al. 2008a, 2008b, 2008c; 


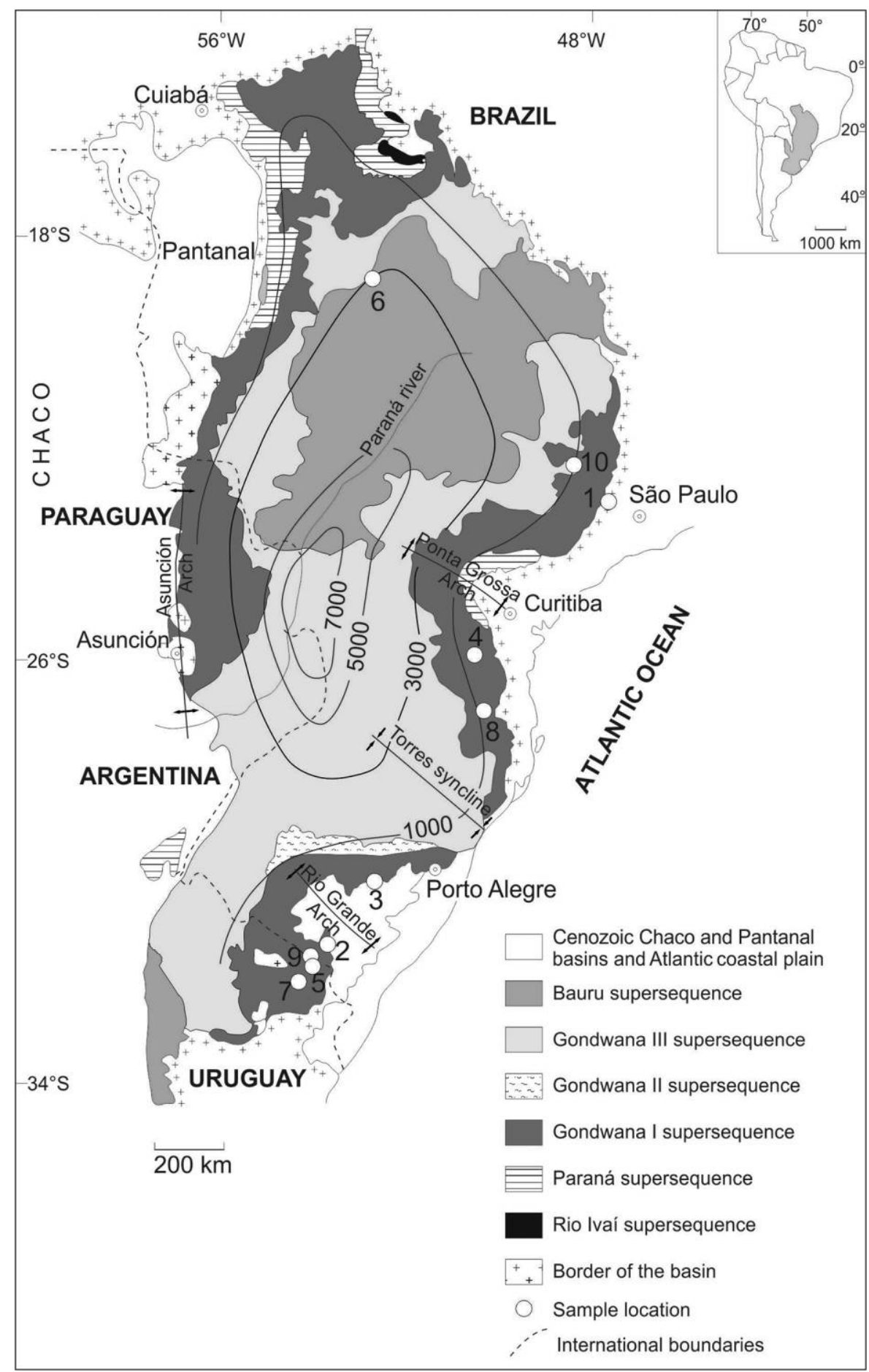

Figure 1. Location of samples and areal distribution of supersequences in the Paraná Basin. Numbers correspond to the stratigraphic succession (see table A1, available online,): 1 = Itararé Group; 2 = Rio Bonito Formation, Candiota; $3=$ Faxinal; 4 = Irati Formation; $5=$ Mangrullo Formation; $6=$ Teresina Formation (well); $7=$ Yauari Formation; 8 = Rio do Rasto Formation, Serrinha Member; 9 = Morro Pelado Member; 10 = Corumbataí Formation (Fernandes 2007). Concentric circles indicate a state capital.

Neregato et al. 2008; Holz et al. 2010; Mori et al. 2012). Figure 2 compares the distribution of $\mathrm{U}-\mathrm{Pb}$ ages obtained with the late Paleozoic chronostratigraphy of the Paraná Basin, using the 2014 International Commission of Stratigraphy timescale for the Carboniferous and Permian. This embodies our $\mathrm{U}-\mathrm{Pb}$ dating controls, presented here, and also previous work (e.g., by Milani et al. 2007; Holz et al. 2010). Spatial relations of units are based on both outcrop and subsurface data, and the time spans are 


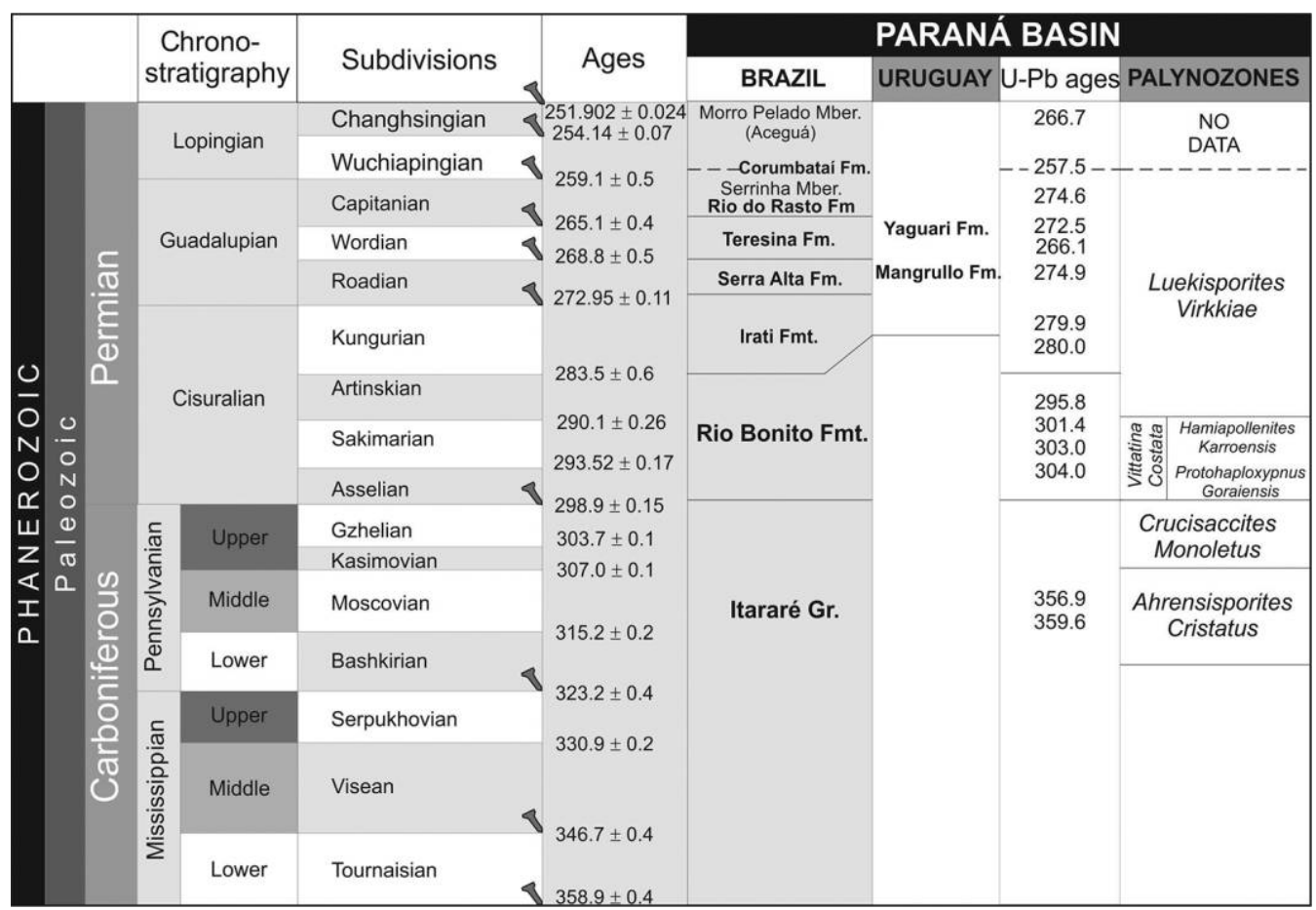

Figure 2. Stratigraphic chart for the late Paleozoic rocks of the Paraná Basin, including the new SHRIMP U-Pb zircon and isotope-dissolution TIMS ages obtained in this research (see text for explanation). The chronostratigraphy is according to the International Commission on Stratigraphy 2018 chart. Fm./Fmt. = Formation; Gr. = Group; Mber. = Member.

based on biostratigraphy (mostly palynological) controls.

Views of different authors regarding spatial relationships (e.g., correlation, interfingering, diachronism), as depicted in figure 4 of Daemon and Quadros (1970), can vary substantially (e.g., Castro 1988). As shown in figure 2, north-south facies variations of units outside of their type localities have often received different formation names. Beds corresponding to the Rio Bonito and Palermo Formations are, for instance, considered as represented in the northern part of the basin by the Tatui Formation (Schneider et al. 1974).

Ash Fall Deposits. The rocks studied (Itararé Group and Rio Bonito, Irati, Mangrullo, Estrada Nova, and Rio do Rasto Formations) correspond mostly to outcrop samples with laminae $(<2.5 \mathrm{~cm}$ thick) or beds $(>2.5 \mathrm{~cm})$ of clayey composition intercalated in other fine-grained lithology (shales, mudstones, fine sandstones) bearing variable amounts of volcanoclastic components, including bentonites (figs. 3, 4). These types of deposits have been called informally "ash fall layers" (AFLs) by Rocha-Campos et al. (2011). Their volcanic pedigree is also shown by their content of dispersed glass shards (Coutinho et al. 1991; Coutinho and Hachiro 2005; fig. 4).
Several AFLs occur within the Rio Bonito Formation at the start of the Permian succession (Holz et al. 2010 and references therein). Within the Irati and Estrada Nova/Teresina Formations and the Serrinha Member of the Rio do Rasto Formation, there are intervals bearing dispersed tephra. These have been denominated "vitroclastic-carrying sediments" (VCSs) by Coutinho and Hachiro (2005) when $>25 \%$ glass shards are observed in thin sections. Until now, AFLs have not been found in the Palermo and Serra Alta Formations (fig. 2). The VCSs from the Irati Formation and others from the Estrada Nova Formation come from wells drilled, respectively, by Petrobras (Petróleo Brasileiro) in the oil shale mine Petrosix, São Mateus, Paraná State, and by Paulipetro (formerly the State of São Paulo Oil Agency) in the northwestern part of the basin (borehole 2-RA-1-MS).

Some AFLs consist of almost pure smectitic bentonite (Irati and Yaguari Formations; Maynard et al. 1996; Mizusaki et al. 1999) or kaolinitic bentonite tonsteins (Rio Bonito Formation; Fabris de Matos et al. 2000, 2001). Tonsteins also contain fragments of coal and plant fossils (Fabris de Matos et al. 2000, 2001; Guerra-Sommer et al. 2006). Bentonites from the Rio Bonito and Irati Formations 

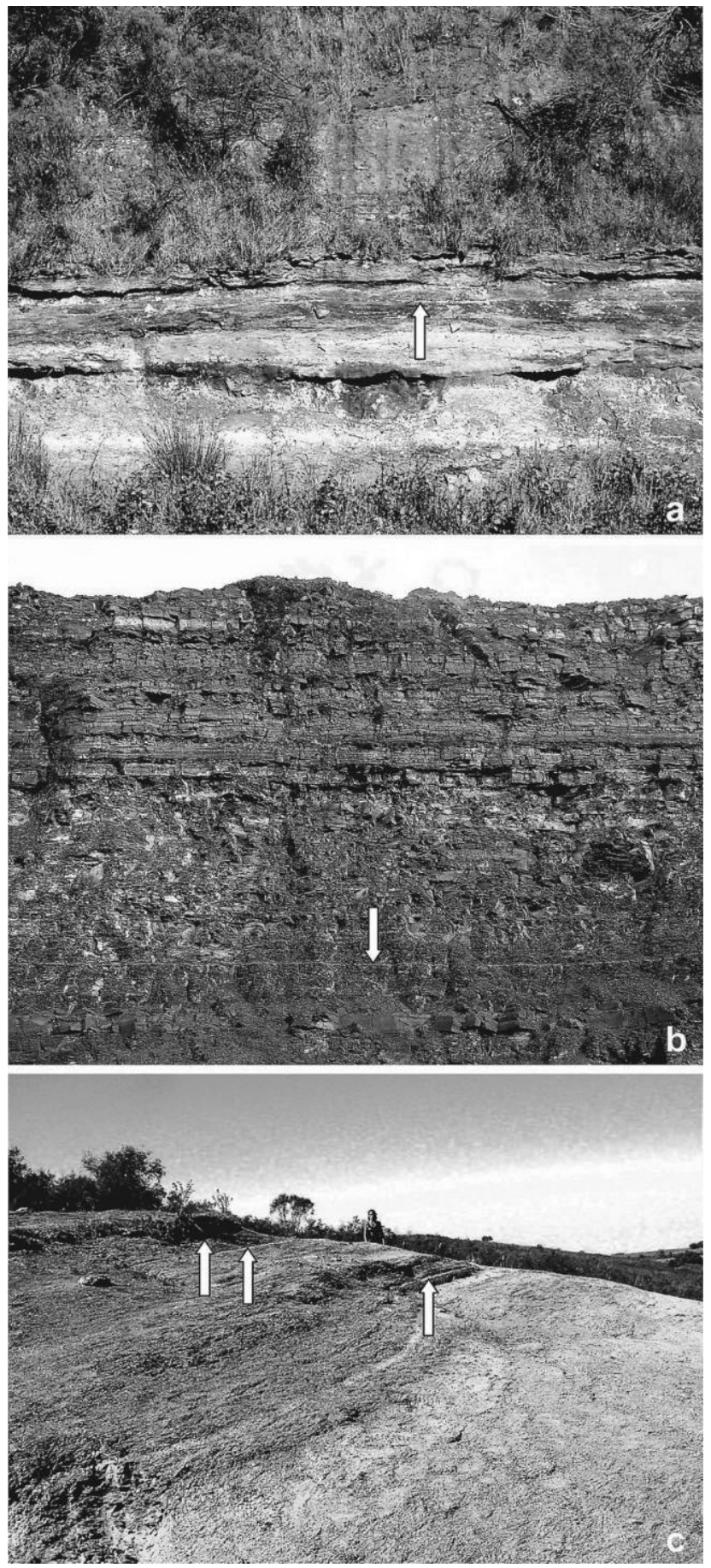

Figure 3. Photographs of selected outcrops. $a$, Tonsteins from the Rio Bonito Formation (sample TA-C1); arrow indicates "Banco Luoco." $b$, Bentonite from the Irati Formation, lower shale (SM-1), Petrobras Petrosix Mine, São Mateus do Sul (arrow). c, Bentonites from the Mangrullo Formation, Cañada del Rodeo del Barón, Uruguay, where layers 4 (EB-1) and 5 (EB-2) were sampled (arrows). Note the shale of the Paso Aguiar Formation (Permian) cropping out on the upper-left side. A color version of this figure is available online. show internal clay laminations and contain carbonized organic fragments, indicative of a composite structure (Rocha-Campos et al. 2011). The AFLs in the Paraná Basin show evidence of subaquatic deposition. With one exception in the Rio do Rasto
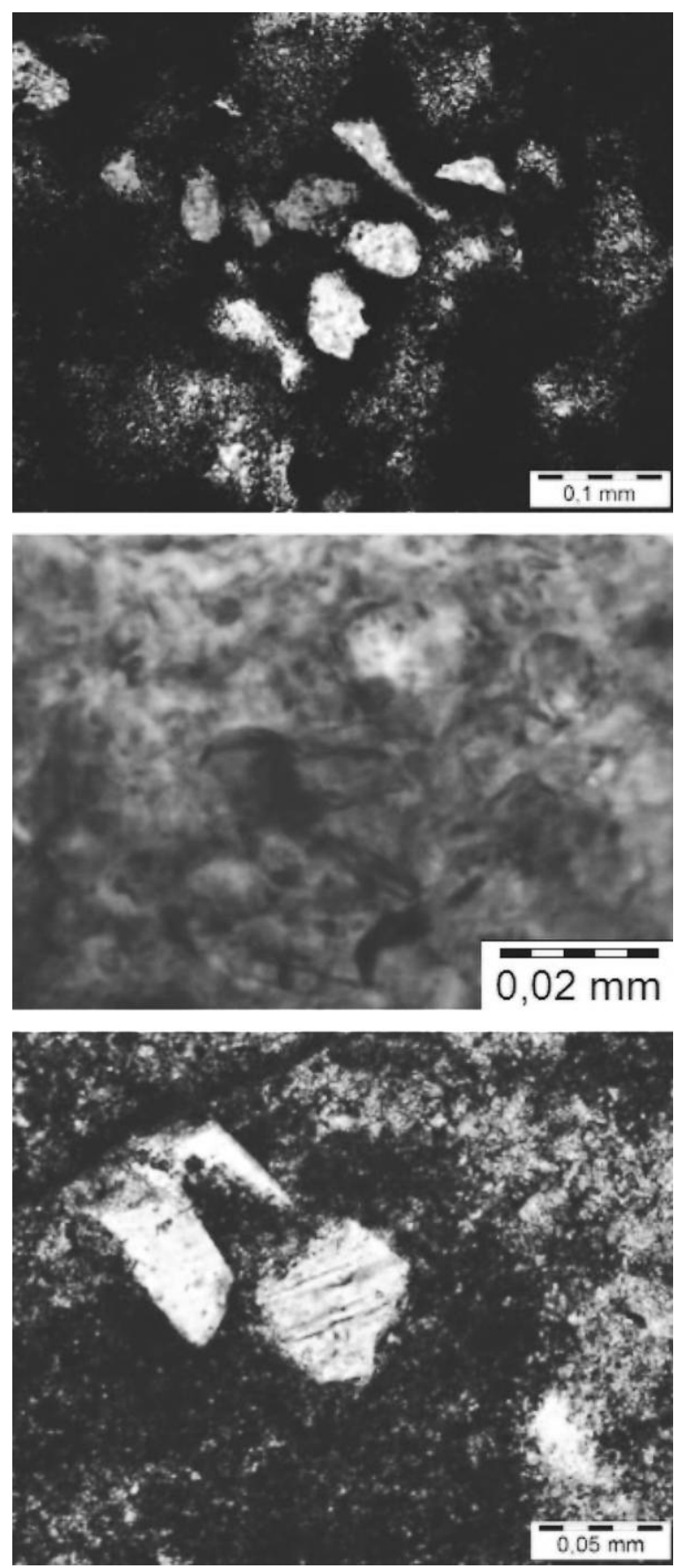

Figure 4. Transmitted-light thin-section images showing possible glass shards amid altered groundmass in the Irati Formation. A color version of this figure is available online. 
Formation, they seem to correspond to shallow marine environmental settings. The AFLs may be continuous for over $25 \mathrm{~km}$, keeping relatively constant thickness (centimeter-decimeter; Fabris de Matos et al. 2001) and lithological characteristics. Consequently, AFLs are potential marker beds for long-distance correlation. Importantly, the number and thickness of AFLs are highly variable. Three of the units dated are remarkable for having a high number of AFLs (Rio Bonito and Irati/Mangrullo Formations) or for their greater thickness (Rio do Rasto/Yaguari Formations). These are presumably related to episodes of more intense and frequent volcanic activity (Rocha-Campos et al. 2011). Figure 1 shows that the samples studied cover a considerable portion of the Paraná Basin at different stratigraphic levels. Localities are, however, mainly situated on the eastern outcrop of the basin, except that for the Estrada Nova Formation, in its northwestern sector.

\section{Zircon U-Pb Geochronology: Analytical Methods and Data Assessment}

All samples were examined petrographically and by $\mathrm{X}$-ray diffraction to identify the clay minerals, in order to check for evidence of volcanic contributions before those for zircon separation were chosen. Twelve samples were selected for zircon U-Pb dating by the SHRIMP method. In most cases, dating was done on populations of carefully selected transparent, euhedral, biterminated grains with sharp corners and internal zonation, typical of zircons of magmatic origin. Their lengths vary from 14 to $180 \mu \mathrm{m}$ (figs. 5, 6). We used SEM back-scattering imagery to check for abrasion on the exterior surfaces of the grains. Figure 5 shows SEM images of grains with perfect euhedral shapes, devoid of surface abrasion. This testifies that they did not suffer aqueous or aeolian transportation before deposition; instead, they are interpreted as dispersed air fall grains from eruptions.

In cathodoluminescence $(\mathrm{CL})$ images, the grains show igneous oscillatory zoning parallel to their exterior (fig. 6). However, the grains are not perfect and show some domains where the igneous oscillatory zonation has been disrupted by later recrystallization (fig. 6). The implication for this is that bulk samples of the AFL zircons (as used in ID-TIMS analysis) might show small, often subtle degrees of recent loss of radiogenic $\mathrm{Pb}$, reducing their apparent ${ }^{206} \mathrm{~Pb} /{ }^{238} \mathrm{U}$ age. The morphology of these zircons contrasts strongly with that of the older grains of prevolcanic provenance. These grains can be rounded, with rough surfaces, and may show truncation of their interior zoning (fig. 5). Zircon morphology is
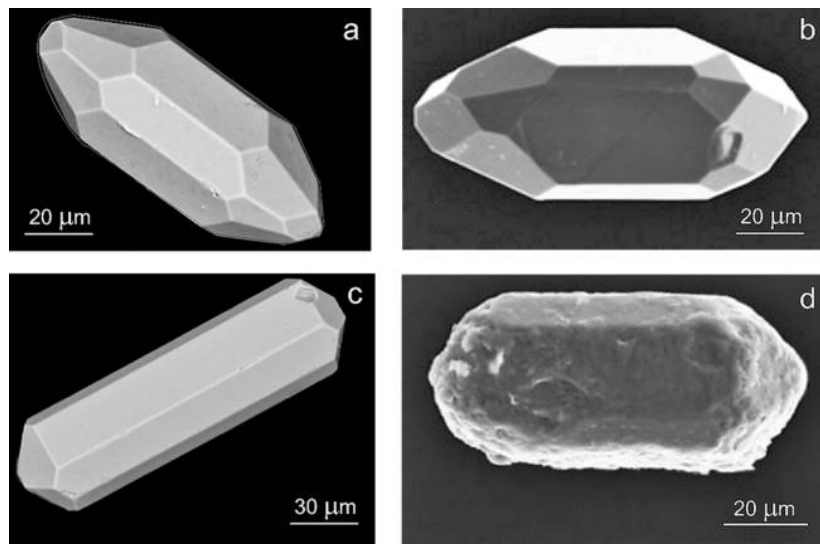

Figure 5. SEM images of zircon crystals. $a$, 2-RA-1-MS, Estrada Nova Formation (Teresina Formation, sample TER-1). b, Serrinha Member (SER-1), Rio do Rasto Formation, volcanic zircon. $c$, Rio Bonito Formation, tonstein Candiota (TA-C1). $d$, Serrinha Member (SER-1), Rio do Rasto Formation, detrital zircon. A color version of this figure is available online.

explored in more detail in "Chronostratigraphic Data."

Zircon separation was by standard gravimetric and isodynamic techniques at the Institute of Geosciences, University of São Paulo. Up to approximately 150 of the most euhedral and least colored zircons were selected from each sample under a binocular microscope, and these were cast into epoxy resin disks, along with grains of the U-Pb reference zircon Temora. The epoxy resin disks were ground to reveal cross sections through the zircons and then polished with diamond paste. Before analysis, CL images were obtained to choose sites for analysis.

Data were calibrated for $U$ abundance by analysis of SL13 zircon $(U=238 \mathrm{ppm})$ at the start and end of the analytical sessions. $\mathrm{U}-\mathrm{Pb}$ isotopic ratios were calibrated with interspersed analyses of the standard zircon Temora $\left({ }^{206} \mathrm{~Pb} /{ }^{238} \mathrm{U}\right.$ age $=417 \mathrm{Ma}$; Black et al. 2004). Age determinations by SHRIMP were performed at the Research School of Earth Sciences, Australian National University (SHRIMP-RG instrument), at the Beijing SHRIMP Center, Chinese Academy of Geological Sciences (China), and at the Institute of Geosciences, University of São Paulo (Brazil). Analytical protocols were according to Compston et al. (1984), Stern (1998), Williams (1998), and Sircombe (2000).

In order to increase confidence in the accuracy of the ${ }^{206} \mathrm{~Pb} /{ }^{238} \mathrm{U}$ ages against the reference standard and to demonstrate whether the unknown samples have the same or different ages, zircons from several samples were mounted together in the same epoxy resin disks and run against each other as well as 

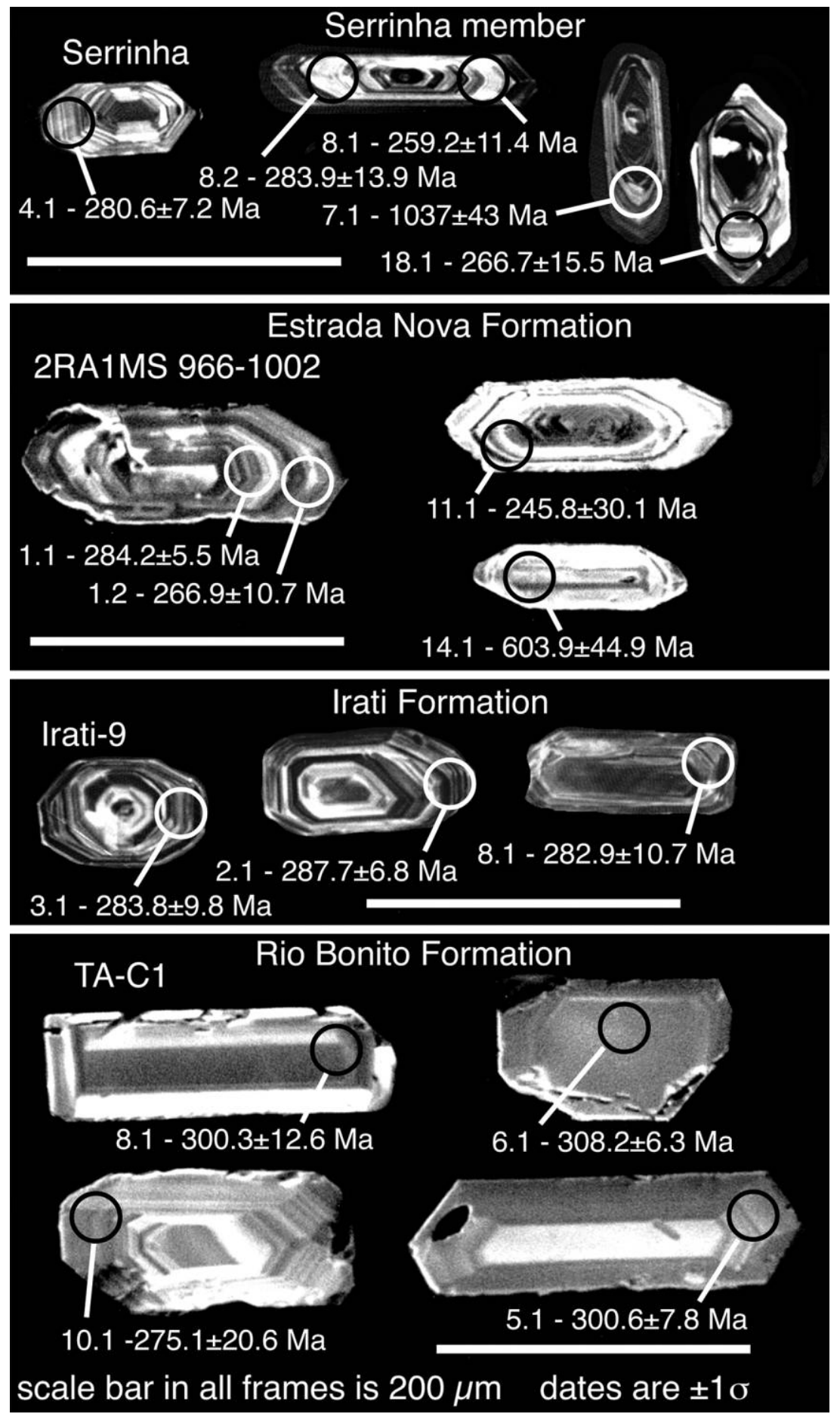

Figure 6. Cathodoluminescence images of representative zircons analyzed. From top to bottom, Serrinha Member, Rio do Rasto Formation; Estrada Nova Formation, Teresina Formation; Irati Formation; and Rio Bonito Formation. A color version of this figure is available online.

against the interspersed $\mathrm{U}-\mathrm{Pb}$ reference zircon $\mathrm{Te}$ mora. Thus, a typical analytical protocol would be Temora, zircon from unknown rock $\mathrm{A}$, zircon from unknown rock $\mathrm{B}$, zircon from unknown rock $\mathrm{C}$, Temora, and so on. To increase confidence in the robustness of the $\mathrm{U}-\mathrm{Pb}$ calibration, Temora grains were distributed as several clusters in different parts of the epoxy mount. These different clusters of Temora grains were visited in a random fashion during the analytical session. This allows the best 
estimate across the mount of the U-Pb calibration and its uncertainty. If the standard is located in a single cluster some distance on the mount from an unknown, then subtle differences in conductivity of the mount's gold coat and any need to slightly refocus the secondary-ion optics for different parts of the mount can lead to a systematic error in the calibration of the U-Pb age for the unknowns.

Some samples were run either on the same SHRIMP instrument in different analytical sessions or on entirely different instruments. In these situations, the different data sets were congruent in terms of ${ }^{206} \mathrm{~Pb} /{ }^{238} \mathrm{U}$ ages. In order to allow comparison with other data and with samples that were analyzed in different mounts, the weighted mean ${ }^{206} \mathrm{~Pb} /{ }^{238} \mathrm{U}$ ages in this article are quoted with the $\mathrm{U}-\mathrm{Pb}$ calibration error added in quadrature.

One additional age determination was performed at the Institute of Geosciences, University of São Paulo, with the ID-TIMS U-Pb technique, according to the procedures described by Passarelli et al. (2009). The sample was an AFL in the basal part of the Corumbataí Formation, the uppermost unit in the state of São Paulo, below the Piramboia Formation of Mesozoic age.

Age calculations used the decay constants and the present value of ${ }^{238} \mathrm{U} /{ }^{235} \mathrm{U}$ from Steiger and Jäger (1977). Ages were calculated after correction for common $\mathrm{Pb}$, using measured ${ }^{204} \mathrm{~Pb}$ and common- $\mathrm{Pb}$ values of Cumming and Richards (1975). For Phanerozoic and Neoproterozoic zircons most reliance was placed on the ${ }^{206} \mathrm{~Pb} /{ }^{238} \mathrm{U}$ ages, and for older grains reliance was placed on the ${ }^{207} \mathrm{~Pb} /{ }^{206} \mathrm{~Pb}$ ages. All U-Pb zircon data are summarized in table A2. Most of the analyses yielded close to concordant ages.

The data were filtered before plotting, to remove analyses with the most obvious disturbance to their radiogenic $\mathrm{Pb}$ systematics and with $>2.5 \%{ }^{206} \mathrm{~Pb}$ of common origin, plus pre-350 Ma inherited grains and analyses with discordant $\mathrm{U}-\mathrm{Pb}$ ages. Because only $\mathrm{U}-\mathrm{Pb}$ age data concordant within error are used, U-Pb concordia diagrams are not presented. Instead, the data are portrayed in probability density plots with histograms in the background, generated by the program Isoplot/Ex (Ludwig 2001). These diagrams cover only the age range $350-250 \mathrm{Ma}$, the likely range for volcanogenic zircons falling into the basin (fig. 7).

One problem to be overcome in the zircon geochronology of AFLs is the occurrence of slightly older volcanic components mixed in with syndepositional ash. These older components can be derived from erosional scavenging of slightly older ash layers within the Paraná Basin itself or directly from their remote volcanic source as older inherited components via the plinian-ultraplinian eruptions. Another problem is variable degrees of slight recent loss of radiogenic $\mathrm{Pb}$ from some sites in the

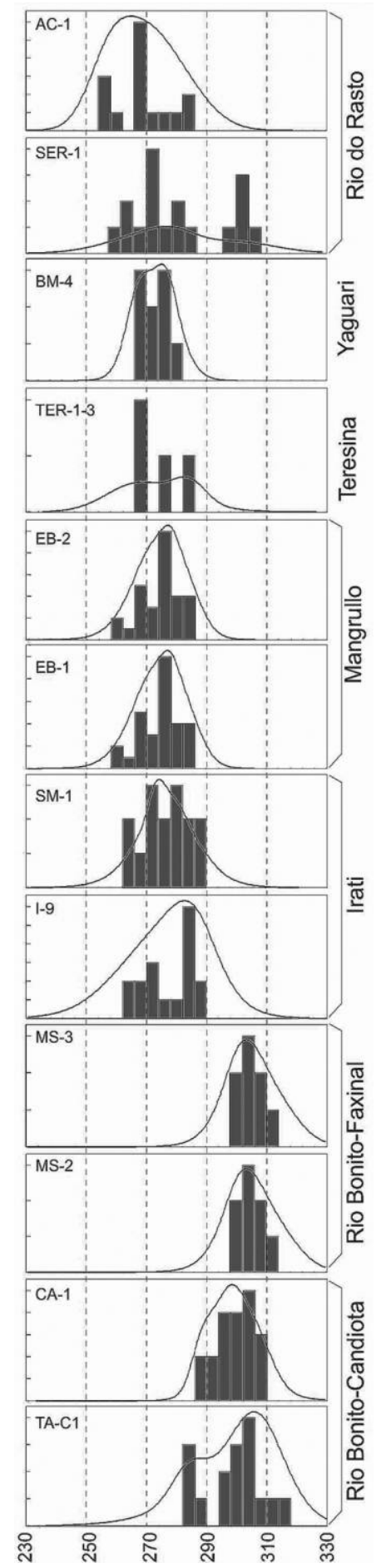

Figure 7. Comparative histograms of selected data obtained on Neopaleozoic dated units. Despite large errors, there is good agreement between the stratigraphic position and the absolute ages. 
zircons, giving rise to a "tail" of apparently younger ages in the probability distribution of ages. Inclusion of slightly older recycled volcanic grains in age determinations will give slightly too old ages, whereas inclusion of analyses on sites with recent loss of radiogenic $\mathrm{Pb}$ will give slightly too young ages. These problems are recurrent in all U-Pb zircon Phanerozoic timescale work using AFLs (e.g., Compston 2000; Mundil et al. 2001; Bowring and Schmitz 2003).

Once initial data filtering/culling was undertaken as outlined above, Occam's Razor- "Pluralitas non est ponenda sine necessitate" ("Entities are not to be multiplied without necessity") — was the guiding principle in data assessment. Overall, the amount of data rejected through the statistical tests and under this guiding principle was very small. For the remaining analyses following the initial filtering, homogeneity of the populations was assessed by using the cumulative-frequency plots and skewness and kurtosis tests of the populations. These monitors in deviation from unimodal Gaussian distributions were used in decisions on how to cull or split the data into subpopulations.

\section{Chronostratigraphic Data}

Itararé Group, Brazil. The Itararé Group, which rests on Precambrian to middle Paleozoic rocks, is a predominantly sandy unit intercalated with diamictite beds, shales, and siltstones. Glacial striations are ubiquitous on granite and sediment underlying diamictites. Most diamictites have been resedimented in marine conditions. It is the thickest late Paleozoic unit of the Paraná Basin (see RochaCampos et al. 2006).

Results for the glaciogenic unit of the Paraná Basin were not satisfactory. Ages were obtained in the northern part of the basin on high-U zircon samples from the Navarro quarry argillite (bentonite?) that overlies stratigraphically the local glacially striated eo-Paleozoic granite basement, including the classical roche moutonnée from Salto (fig. 1), and from the "Passinho" shale in the central part of the basin. The Navarro argillite is followed up by the still-unnamed lower gray shale unit extensively exposed near Itu and mapped by Viviani and Rocha-Campos (2002; fig. 1). Only detrital zircons were recovered from several samples taken from the "Passinho" and Cerâmica Navarro quarry (fig. 1; tables A1, A2). Relatively few Phanerozoic zircons are present in the samples, and they indicate a provenance from Precambrian fold belts of Neoproterozoic and Paleoproterozoic ages. Two grains from the Itararé shaly beds at Itu yielded ages of
$356.9 \pm 22 \mathrm{Ma}$ (sample JBV-73; Tournaisian, early Mississippian) and 359.6 $\pm 8.1 \mathrm{Ma}$ (sample AP-1; late Devonian). Less reliable, having been obtained on a high-U zircon, is the age of $323.6 \pm 15 \mathrm{Ma}$ (late Mississippian) on "Passinho" shale (Rocha Campos et al. 2007). A palynogical determination of the Itu shale yielded specimens of prasynophiceans, chlorophicean, and zygnematacean algae (Souza et al. 2010), which the authors interpreted as of shallow, brackish facies and middle Pennsylvanian age. Rare glacial rafting is recorded by isolated clasts. The above age is compatible with other biostratigraphic results from Souza et al. (2010), who interpreted the results as indicative of the oldest possible age for the lowermost Itararé (323 Ma). We accept this age (Pennsylvanian) as the lower limit for the Itararé Supergroup.

Rio Bonito Formation (Brazil). The unit and equivalent beds, predominantly sandy, constitute a coalbearing sequence cropping out along the entire eastern and western outcrop belts of the basin. Around the Rio Grande Arch, the Rio Bonito Formation and the restricted Itararé beds are known to occur in elongate depressions that radiate from the arch and have been compared to fjords (Santos et al. 1996). In all the basins, the Rio Bonito is associated with coal beds (Eyles et al. 1993; Holz et al. 2010). In spite of excellent outcrops and the presence of bentonite, we restricted the sampling to the basins around the Rio Grande Arch. We also took into consideration the existence of previously published U-Pb dates (e.g., Fabris de Matos et al. 2001; GuerraSommer et al. 2008a, 2008b, 2008c; Mori et al. 2012) and the robust palynological support developed for the area (e.g., Souza and Marques-Toigo 2005).

Radiometric $\mathrm{U}-\mathrm{Pb}$ ages (table A2) have been determined for tonsteins from the Candiota and Faxinal-Leão coal subbasins in the south and north, respectively, of the Rio Grande Arch (fig. 1; see table A1 for sample descriptions) in the southernmost part of Paraná Basin. Older detrital zircons are rare. The homogeneity of the populations suggests that they may represent ash fall events and not the recycling of older detritus. Age determinations on four samples are as follows.

Candiota lower seam, lower tonstein, sample $T A-C 1$. Sixteen analyses of likely volcanogenic zircons give a weighted mean age of $297.3 \pm 4.7 \mathrm{Ma}$ $(M S W D=1.4)$. The slight skewness giving a "young" tail in this population might be due to some radiogenic $\mathrm{Pb}$ loss. Rejecting two analyses on this basis gives a weighted mean age of 304.0 \pm $5.6 \mathrm{Ma}$ (MSWD =0.3; fig. $8 A$ ). Sample TA-Cl is from the same layer that was dated by Fabris de Matos et al. (2001; fig. 3). 

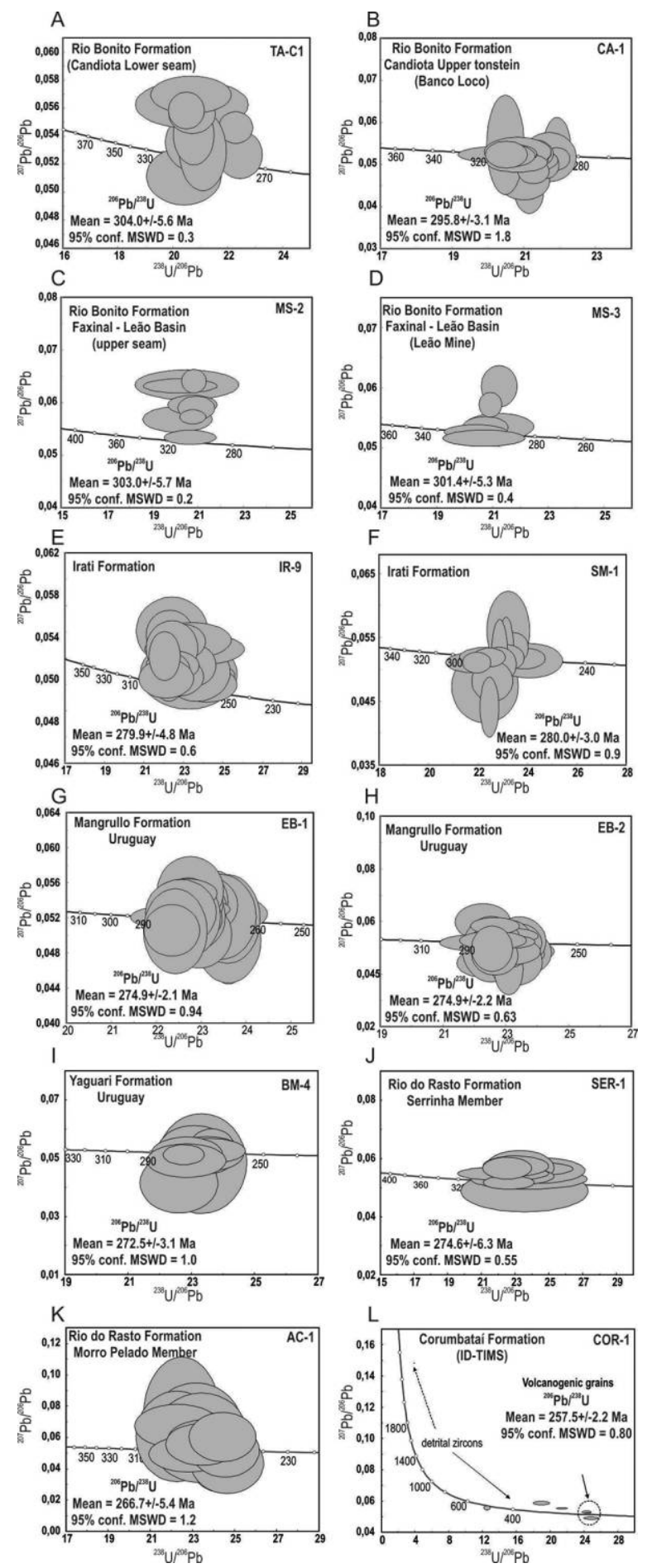

Figure 8. U-Pb plots of the 11 SHRIMP U-Pb zircon ages and one ID-TIMS age obtained. The sequence of ages is consistent with the accepted stratigraphic sequence of the late Paleozoic units.

Candiota upper tonstein ("Banco Louco"), sample $C A-1$. Twenty-three U-Pb measurements were undertaken. Unfiltered, 20 likely volcanogenic zircons give a weighted mean age of $295.8 \pm 3.1 \mathrm{Ma}$
(MSWD $=1.8$ ). The young tail in this population shows some evidence of radiogenic $\mathrm{Pb}$ loss (compare the ages on two sites on grain 1 ; table A2). Rejecting one analysis (6.1) because of minor loss of radiogenic $\mathrm{Pb}$ and two analyses with inheritance (7.1 and 11.1) gives a weighted mean age of $295.8 \pm$ $3.1 \mathrm{Ma}$ (MSWD = 1.0; fig. $8 B$ ). This sample is $4.2 \mathrm{~m}$ above the former, along the section measured by Fabris de Matos et al. (2001; fig. 3).

Faxinal-Leão basin upper seam (Mori et al. 2012), sample MS-2. Without any rejections, eight analyses of likely volcanogenic zircons give a weighted mean age of $303.0 \pm 5.7 \mathrm{Ma}$ (MSWD = 0.2; fig. 8C).

Faxinal-Leão basin upper seam (Leão mine), sample MS-3. With rejection of highly discordant spots 1.1 and 6.1, six analyses of likely volcanogenic zircons give a weighted mean age of $301.4 \pm 5.3$ (MSWD = 0.4; fig. 8D).

In all of the Rio Bonito Formation samples, older detrital zircons are rare (table A2). The available radiometric ages indicate consistent differences between coals in the northern Faxinal-Leão coal seam and those in the Candiota seam.

Irati Formation (Brazil). Outcrop and subsurface data on the Irati Formation demonstrate that it is a thin (28-40 $\mathrm{m}$ in outcrop and up to 60-71 $\mathrm{m}$ thick in subsurface; Schneider et al. 1974; Castro 1988), horizontal, and essentially isochronic unit.

Samples dated from the Irati Formation (tables A1, A2) are SM-1, from a 2-3-cm-thick bentonite layer from the middle part of the 3-m-thick lower oil shale bed (Castro 1988; Maynard et al. 1996; fig. 3B), and bentonite core sample IR-9, from a shallow well drilled at the same locality. The stratigraphic position of samples is not known with certainty, but they seem to represent the same level. Seventeen U-Pb analyses of sample IR-9 yielded a coherent population with a weighted mean age of $279.9 \pm 4.8 \mathrm{Ma}$ $(\mathrm{MSWD}=0.6$; fig. $8 E)$. Eighteen analyses were undertaken on surface bentonite sample SM-1 zircons. This population is slightly skewed. With three analyses rejected for young ages, interpreted as resulting from loss of radiogenic $\mathrm{Pb}$, the remaining 15 give a weighted mean age of $280.0 \pm 3.0 \mathrm{Ma}$ (MSWD $=0.9$; fig. $8 F$ ). In both samples, these ages are interpreted as dating syndepositional volcanogenic events. They are also coincident with results obtained by Santos et al. (2006) on samples from the same locality.

Mangrullo Formation (Uruguay). The correlation between the Irati Formation and the Mangrullo Formation (maximum thickness of $33 \mathrm{~m}$ ) of northeastern Uruguay (de Santa Ana et al. 2006) is a wellaccepted concept. The unit crops out in the Northern Basin of Uruguay. Its correlation is also supported by paleontologic evidence (presence of mesosaurids, crus- 
taceans, etc.). Dated samples came from two bentonite laminae, $3 \mathrm{~cm}$ thick, intercalated in pyrobituminous shale cropping out at Cañada del Rodeo del Barón. They occur in the upper part of the formation, immediately below the Paso Aguiar Formation (de Santa Ana et al. 2006). The two sampled AFLs, at a $50-\mathrm{cm}$ vertical interval from each other, are the stratigraphically highest of a series of at least five main bentonitic layers visible in the section (fig. $3 C$ ).

Thirty $\mathrm{U}-\mathrm{Pb}$ analyses were undertaken on zircons from the lower sample, EB-1 (tables A1, A2). One analysis was rejected because its age is stratigraphically much too young (Triassic), and the grain has undoubtedly been disturbed. The remaining analyses yielded a weighted mean age of $275.0 \pm 2.4 \mathrm{Ma}$ $(\mathrm{MSWD}=1.5)$. This population seems to be unimodal, with a tail of younger analyses giving a skew to the distribution. If two analyses with higher ${ }^{207} \mathrm{~Pb} /{ }^{206} \mathrm{~Pb}$ errors and the five youngest ages, interpreted as showing minor loss of radiogenic $\mathrm{Pb}$, are rejected, the remaining ones give a weighted mean age of $274.9 \pm 2.1 \mathrm{Ma}$ (MSWD = 0.94; fig. $8 G$ ).

Thirty-five analyses were undertaken on sample EB-2 zircons (table A2). Two analyses with ages of 314 and $403 \mathrm{Ma}$ were rejected because they are clearly inherited (old) components. Spots 1.1, 2.1, and 9.1 were also rejected because of the higher error in the ${ }^{207} \mathrm{~Pb} /{ }^{206} \mathrm{~Pb}$ ratios. The remaining analyses yielded a weighted mean age of $271.3 \pm 2.5 \mathrm{Ma}$ (MSWD = 1.6). In structure, this population seems to be unimodal, with a tail of younger analyses giving a skew to the distribution. If the six youngest ages (including one with an upper Permian age) are interpreted as showing minor loss of radiogenic $\mathrm{Pb}$, the remaining ones give a weighted mean age of $274.9 \pm 2.2 \mathrm{Ma}(\mathrm{MSWD}=0.63$; fig. $8 H$ ). The filtered weighted mean ages are interpreted as dating syndepositional volcanogenic events.

Estrada Nova Formation (Teresina Formation, Brazil). The stratigraphy of this part of Supersequence I is a little bit confusing and deserves an initial clarification. The sample analyzed consisted of siltstone cuttings from depths of $933-963 \mathrm{~m}$ in well 2-RA-1-MS (sample TER-1; tables A1, A2), provided by Paulipetro, located close to the northwestern border of the basin (fig. 1). The siltstones are broadly designated as the Estrada Nova Formation, a lateral equivalent to the Teresina Formation (Schneider et al. 1974). White (1908) proposed the name Estrada Nova Formation to include the Serra Alta and Teresina Formations, but it did not gain general use.

Most of the recovered zircons are definitely detrital, with ages ranging from lower Ordovician to Neoproterozoic (table A2). Analyses 10.1, discordant with a ${ }^{206} \mathrm{~Pb} /{ }^{238} \mathrm{U}$ age of $\sim 400 \mathrm{Ma}, 5.1$, with a
${ }^{206} \mathrm{~Pb} /{ }^{238} \mathrm{U}$ age of $\sim 310 \mathrm{Ma}$, and high-U analysis 9.1, with a ${ }^{206} \mathrm{~Pb} / 238 \mathrm{U}$ age of $\sim 200 \mathrm{Ma}$ (and thus clearly disturbed), were also rejected. This left four analyses $(1.1,1.2,3.1$, and 7.1) as potential candidates for volcanogenic input. The ${ }^{206} \mathrm{~Pb} /{ }^{238} \mathrm{U}$ ages for analyses 1.1 and 1.2, on opposite tips of the same grain, do not agree within error, indicating that this grain has been isotopically disturbed, suffering some loss of radiogenic $\mathrm{Pb}$. Rejecting "older" analysis 1.1 and combining analyses 1.2 and 7.1 gives a weighted mean ${ }^{206} \mathrm{~Pb} /{ }^{238} \mathrm{U}$ age of $266.5 \pm 7.1 \mathrm{Ma}(\mathrm{MSWD}=0.01$ ). This age is compatible with a volcanogenic origin. However, little confidence can be placed in establishing the age of the Estrada Nova Formation with this zircon analysis. Because of the scarce number of data, no plot is shown for this sample.

Yaguari Formation (Uruguay). Zircon ages for the Yaguari Formation come from a 2-m-thick bentonite bed belonging to the upper of two members /de Santa Ana et al. 2006; Veroslavsky et al. 2006) exposed in a pit at Bañado del Medina, $20 \mathrm{~km}$ west of the town of Melo, Uruguay (fig. 1). The unit is an up to $100-\mathrm{m}$-thick succession of variegated, shallowmarine (tidal) fine sandstones and shales (de Santa Ana et al. 2006). It is usually correlated with the upper Estrada Nova/Teresina Formation or basal parts of the Rio do Rasto Formation (Serrinha Member?) of Brazil (Piñeiro 2006). Detailed mineralogical studies by Zalba et al. (1993) and Calarge et al. (2003) have shown the nearly pure and highly crystallized smectitic (mostly montmorillonite) composition of both the Yaguari and the Aceguá bentonites.

Twenty-seven $\mathrm{U}-\mathrm{Pb}$ analyses were undertaken on Yaguari Formation bentonite zircons (sample BM-4; tables A1, A2). Sixteen analyses are derived from 300 Ma to Archean sources and as older detrital grains are considered no further. Two other analyses (5.1 and 9.1) with large analytical errors and ages of $\sim 290 \mathrm{Ma}$ were also rejected. The remaining nine analyses give a ${ }^{206} \mathrm{~Pb} /{ }^{238} \mathrm{U}$ weighted mean age of $272.5 \pm 3.1 \mathrm{Ma}(\mathrm{MSWD}=1.0$; fig. 8I). This population is distinctly non-Gaussian, with probably two groups present. If these are treated separately, then the younger group gives an age of $267.8 \pm 4.6 \mathrm{Ma}$ $(n=4, \operatorname{MSWD}=0.02)$, whereas the older group gives an age of $276.4 \pm 4.2 \mathrm{Ma}(n=5, \mathrm{MSWD}<0.1)$. On this premise, the maximum age of deposition of this sample is $267.8 \pm 4.6 \mathrm{Ma}$.

Rio Do Rasto Formation (Serrinha Member, Brazil). The Serrinha Member forms the lower part of the Rio do Rasto Formation and comprises about $250 \mathrm{~m}$ of reddish to variegated siltstones and fine lacustrine sandstones. The Morro Pelado Member forms the upper part of the formation and is an about 200-mthick package of interbedded fluviatile, lenticular, 
cross-bedded sandstone and shale (Holz et al. 2010 and references therein). The three samples of the Serrinha Member dated come from the middle part of a cut at km 195.5 of road BR-470, in the state of Santa Catarina, Brazil. The Morro Pelado sample dated is a high-quality VCS sample for this member collected from a 40-cm-thick bentonite bed intercalated in reddish lacustrine shale and fluviatile sandstone and cropping out at a quarry approximately $3 \mathrm{~km}$ north of the town of Aceguá (state of Rio Grande do Sul, Brazil), on highway RS-473. The lithofacies is considered part of the Morro Pelado Member.

The Serrinha Member gave a small yield of zircons, with ages ranging from upper Paleozoic to Mesoproterozoic (sample SER-1; tables A1, A2). Fifteen analyses remained after initial culling, with ${ }^{206} \mathrm{~Pb} /{ }^{238} \mathrm{U}$ ages ranging from 307 to $259 \mathrm{Ma}$. The age distribution of these is non-Gaussian, with a distinct group of five older analyses. These five give a weighted mean ${ }^{206} \mathrm{~Pb} / 238 \mathrm{U}$ age of $302.0 \pm 11.0 \mathrm{Ma}$ (MSWD $=0.1)$, which is compatible with derivation from Rio Bonito Formation ash layers. With these removed, the remaining 10 analyses have a symmetric Gaussian ${ }^{206} \mathrm{~Pb} /{ }^{238} \mathrm{U}$ age distribution, with a weighted mean age of $274.6 \pm 6.3 \mathrm{Ma}$ (MSWD = 0.55 ; fig. 8J). This is too old for the assigned stratigraphic position of the Serrinha Member. However, there are no grounds based on either statistics or zircon morphology to divide further this population of 12 ages. Thus, these, like the $302.0 \pm 11.0 \mathrm{Ma}$ population, could also be recycled grains. In which case, the age of deposition of the Serrinha Member is $<274.1 \pm 5.0 \mathrm{Ma}$ (MSWD $=0.6$ ).

Rio Do Rasto Formation (Morro Pelado Member, Brazil). Seventeen analyses were undertaken on zircons from the upper Rio do Rasto Formation, at Aceguá, Rio Grande do Sul State (sample AC-1; tables A1, A2). Three analyses were initially rejected: 16.1, which is an inherited Mesoproterozoic grain, and 6.1 and 12.1, with discordant $\mathrm{U}-\mathrm{Pb}$ ages. The remaining 14 analyses give a weighted mean age of $266.7 \pm 5.4 \mathrm{Ma}$ (MSWD = 1.2; fig. 8K). However, this population has a non-Gaussian distribution with kurtosis, with possibly three distinct ages present (table A1). If there is a tripartite division of this population, then their ages are $257.5 \pm$ $6.9 \mathrm{Ma}(n=4, \mathrm{MSWD}<0.1), 272.7 \pm 5.5 \mathrm{Ma}(n=$ 7, $\mathrm{MSWD}=0.5)$, and $280.5 \pm 9.4 \mathrm{Ma}(n=4$, MSWD $=0.1$. This would give a maximum depositional age of $257.5 \pm 6.9 \mathrm{Ma}$, in the upper Permian (Wuchiapingian).

Corumbataí Formation (Brazil). The zircons were extracted from two thin probable AFLs interbedded with siltstones and argillites in the lower part of the Corumbataí Formation, in a quarry near Limeira,
São Paulo State (sample COR-1; tables A1, A2). The strata are $34 \mathrm{~m}$ below an unconformity, above which is the Triassic Piramboia Formation.

Fernandes (2007) presented ID-TIMS results for these zircons. They are small, euhedral prisms. Three fractions yielded a weighted mean ${ }^{206} \mathrm{~Pb} / 238 \mathrm{U}$ age of $257.5 \pm 2.2 \mathrm{Ma}(\mathrm{MSWD}=0.8$; fig. $8 L)$, whereas other fractions yielded older, Paleozoic ages. If these zircons are not disturbed by loss of radiogenic $\mathrm{Pb}$, this would suggest an upper Permian depositional age (Wuchaipigian). This would conflict with stratigraphic evidence that in São Paulo State there was deep erosion of the Passa Dois Group in the late Permian, such that the Triassic Piramboia Formation rests directly on the lower parts of the group (Holz et al. 2010; fig. 2). This result bears on the question of the nature of the contact between the Corumbataí and the overlying Piramboia and its chronostratigraphic significance (Holz et al. 2010; fig. 2).

\section{Final Remarks}

Maximum depositional ages for strata within the Paraná Basin are integrated with the biostratigraphic record and with models of sedimentary facies distribution and correlations across the basin. We also discuss our U-Pb zircon results in the context of those previously published for AFLs in a more limited stratigraphic interval. The data are also broadly coincident in spite of the different nature and quality of the sampled material: AFLs, VCSs, and tonsteins, with samples from both shallow and deep subsurface well cuttings as well as outcrops. On the basis of the ages it is possible to estimate the chronological interval of the Gondwana I Supersequence of at least $40 \mathrm{My}$. Rocha-Campos et al. (2011) presented U-Pb zircon dating of the Choiyoi volcanic province on the western margin of Gondwana. These dates provide the framework for establishing volcanogenic events affecting the Paraná Basin, versus recycling of volcanic dust via aqueous and aeolian transport.

The available radiometric ages indicate consistent age differences between coal seams in the northern (Faxinal-Leão coal seams) and southern (Candiota seam) local basins adjacent to the Rio Grande do Sul high (Rocha-Campos et al. 2006, 2007 and this article; table A2).

Except for isopach maps, no other information could be found on the thickness (maximum of $350 \mathrm{~m}$ in outcrop) of the Rio Bonito Formation in Rio Grande do Sul. The thickness of the coaly interval of the upper Candiota seam is $\sim 273 \mathrm{~m}$. Two recent 
published SHRIMP ages of the Rio Bonito tonsteins are relevant for understanding the question of age of the coaly interval in subbasins around the Rio Grande Arch. From the upper part of the section, $2 \mathrm{~m}$ below the contact with the Palermo Formation, Mori et al. (2012) obtained a tonstein age of $281.4 \pm 3.4 \mathrm{Ma}$, interpreted to correspond to the uppermost Rio Bonito Formation, while Simas et al. (2012) assigned $291 \pm 12 \mathrm{Ma}$ as the mean age of the regional peatforming interval. Within this context, the older ages of $302.5 \pm 4.8$ and $303.0 \pm 5.7 \mathrm{Ma}$ for tonsteins from the Faxinal-Leão basins (Rocha-Campos et al. 2007; this article), when compared with ages obtained for coals from the southern Candiota seam, are interpreted as possibly indicating that material from an older volcanic episode was reworked into the tonstein. The age of $298 \mathrm{Ma}$, in the Gzelian (latest Pennsylvanian), may be taken as representing the basal Rio Bonito Formation.

It is worth noting that the available stratigraphy and age of coal beds may differ in different areas in the Paraná Basin and therefore that it is not possible to extend the age obtained to other coal seams from the states of Paraná or Santa Catarina (Daemon and Quadros 1970; Souza and Marques-Toigo 2005; Souza 2006). Furthermore, the tripartite subdivision of the Rio Bonito into the Triunfo (deltaic, with thicker coal seams), Paraguaçu (deltaic, shallow marine), and Siderópolis (shallow marine) Members that characterize the Rio Bonito Formation in the state of Santa Catarina (Schneider et al. 1974) cannot be recognized elsewhere in the basin, thus making correlation uncertain (Castro 1988).

The palynological context of the samples analyzed includes the Rio Bonito Formation almost entirely in the Vittatina costabilis biozone of Permian age (fig. 2). Other indicators of Permian age arrive from the Taió mollusk assemblage, which contains taxa (Heteropecten, Myonia, Stutchburia, Oriocrassatella, etc.) that have affinities with Permian assemblages from Australia (Rocha-Campos 1970). The appearance of glossopterid leaves at the Carboniferous-Permian boundary is another widely accepted concept in the Gondwana area (Bernardesde-Oliveira et al. 2005).

\section{Conclusions}

Volcanic Source Region. There is coincidence between ages of the late Paleozoic volcanic detritus in the Paraná Basin and ages of volcanic units in their putative source in the Choiyoi Igneous Province in western Argentina (Rocha-Campos et al. 2011; fig. 9). Thus, the Rio Bonito age $(298.0 \pm 2.0 \mathrm{Ma})$ matches

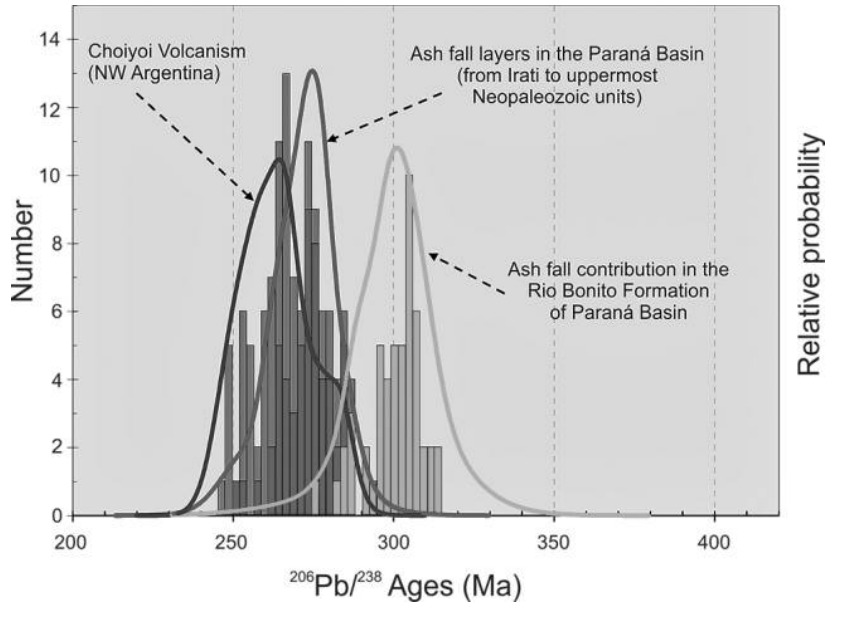

Figure 9. Histogram of zircon ages from the Choiyoi Formation, Choiyoi Igneous Complex, southwest Argentina (Rocha-Campos et al. 2011). Ages of the Choiyoi Formation volcanism can be correlated with Paraná ash fall layers, with the exception of the Rio Bonito Formation. A color version of this figure is available online.

the El Imperial Formation age of $297.2 \pm 5.3 \mathrm{Ma}$ (though measured on a single grain); the Irati age $(276.7 \pm 2.3 \mathrm{Ma})$ matches the lower Choiyoi Formation age of $281.4 \pm 2.5 \mathrm{Ma}$; and the Teresina and Rio do Rasto ages $(273.7 \pm 5.6,269.0 \pm 1,3$, and $266.7 \pm 4.3 \mathrm{Ma}$ ) largely match the middle Choiyoi Formation ages of $264.8 \pm 2.3$ and $264.5 \pm 3.0 \mathrm{Ma}$ (fig. 9). This congruence in ages reinforces the linkage between this peri-Gondwanan volcanism and the Paraná Basin AFLs (Rocha-Campos et al. 2011).

Prevolcanic Source. Precambrian detrital zircon ages from the Itararé Group indicate a predominant provenance from the basement of the Paraná Basin. Rocks of $600 \mathrm{Ma}$ are widespread in the basement rocks of Paraná Basin (Basei et al. 2010). On the other hand, ages of around $1000 \mathrm{Ma}$ are exotic in this area of southeastern South America (Basei et al. 2008). The possible source areas for the 1000 Ma population are the Namaqua belt, which outcrops at the southwestern border of Kalahari craton in South Africa, and the Grenvillian terranes accreted to the western border of the Rio de la Plata craton, which occur in the central-northwestern region of Argentina.

The ages (11 SHRIMP zircon U-Pb and one IDTIMS) reported here are, overall, consistent with the biostratigraphy within the examined interval of the Paraná Basin Gondwana 1 Supersequence. The ages indicate deposition for $40 \mathrm{My}$, from the Gzelian (uppermost Carboniferous) to the Wachumpingian (upper Permian). 
There is coincidence between ages of the late Paleozoic volcanic detritus in the Paraná Basin and volcanic units in their putative source in the Choiyoi Igneous Province in western Argentina (RochaCampos et al. 2011). This congruence in ages reinforces the linkage between this peri-Gondwanan volcanism and the Paraná Basin AFLs (fig. 9).

\section{A C KNOWLEDGMENTS}

We are grateful to Petrobras for providing the support for development of this project. We thank C. E. V. de Toledo for furnishing subsurface samples from wells at the Petrobras São Mateus do Sul mine, Paraná, Brazil.

\section{R E F E R E N C E S C I T E D}

Almeida, F. F. M. de. 1980. Tectônica da bacia do Paraná. Relatório Técnico IPT (Instituto de Pesquisas Tecnológicas) 14091. São Paulo, Paulipetro, 187 p.

Basei, M. A. S.; Brito Neves, B. B.; Siga, O., Jr.; Babinski, M.; Pimentel, M. M.; Tassinari, C. C. G.; Hollanda, M. H. B.; Nutman, A. P.; and Cordani, U. G. 2010. Contribution of SHRIMP U-Pb zircon geochronology to unravelling the evolution of Brazilian Neoproterozoic fold belts. Precambrian Res. 183:112-144. doi:10.1016 /j.precamres.2010.07.015.

Basei, M. A. S.; Frimmel, H. E.; Nutman, A. P.; and Preciozzi, F. 2008. West Gondwana amalgamation based on detrital zircon ages from Neoproterozoic Ribeira and Dom Feliciano belts of South America and comparison with coeval sequences from SW Africa. In Pankhurst, R. J.; Trouw, R. A. J.; Brito Neves, B. B.; and de Wit, M. J., eds. West Gondwana: pre-Cenozoic correlations across the South Atlantic region. Geol. Soc. Lond. Spec. Publ. 294:239-256.

Bernardes-de-Oliveira, M. E.; Kavali, P. S.; Mune, S. E.; Shivanna, M.; Souza, P. A. de; Iannuzzi, R.; Jasper, A.; et al. 2016. Pennsylvanian-Early Cisuralian interglacial macrofloristic succession in Paraná Basin of the state of São Paulo. I. S. Am. Earth Sci. 72:351374.

Bernardes-de-Oliveira, M. E.; Rohn, R.; Ricardi-Branco, F.; Zampirolli, A. P.; Mune, S. E.; Amaral, P. G. C. do; Longhim, M. E.; Castro-Fernandes, M. C.; and Lages, L. 2005. Late Carboniferous and early Permian glacial related paleofloras from northeastern Paraná Basin, Brazil. In International Gondwana Symposium, 12th (Mendoza, Argentina, Nov. 6-11), Actas, p. 70.

Black, L. P.; Kamo, S. L.; Allen, C. M.; Davis, D. W.; Aleinikoff, J. N.; Valley, J. W.; Mondil, R.; et al. 2004. Improved ${ }^{206} \mathrm{~Pb} /{ }^{238} \mathrm{U}$ microprobe geochronology by the monitoring of a trace-element-related matrix effect; SHRIMP, ID-TIMS, ELA-ICP-MS and oxigen isotope documentation for a series of zircon standards. $\underline{\text { Chem. }}$ Geol. 205:115-140.

Bowring, S. A., and Schmitz, M. D. 2003. High-precision $\mathrm{U}-\mathrm{Pb}$ zircon geochronology and the stratigraphic record. Rev. Mineral. Geochem. 53:305-326.

Calarge, L. M.; Meunier, A.; and Formoso, M. L. L. 2003. A bentonite bed in the Aceguá (RS, Brazil) and Melo (Uruguay) areas: a highly crystallized montmorillonite. I. S. Am. Earth Sci. 16(2):187-198.

Castro, J. C. 1988. Sedimentology, stratigraphy and paleontology of the Gondwana Sequence of the Paraná
Basin. In International Gondwana Symposium, 7th (São Paulo, Brazil, July 11-16). Excursion A2 guidebook, $47 \mathrm{p}$.

Compston, W. 2000. Interpretation of SHRIMP and isotope dilution zircon ages for the geological timescale: I. The early Ordovician and late Cambrian. Mineral. Mag. 64:43-57.

Compston, W.; Williams, T. S.; and Meyer, C. 1984. U-Pb geochonology of zircons from lunar breccia 73217 using a sensitive high mass-resolution ion microprole. I. Geophys. Res. 89:525-534.

Coutinho, J. M. V., and Hachiro, J. 2005. Distribution, mineralogy, petrography, provenance and significance of Permian ash-carrying deposits in the Paraná Basin. Geol. USP Ser. Cient. 5(1):29-39. doi:10.5327 /S1519-874X2005000100003.

Coutinho, J. M. V.; Hachiro, J.; Coimbra, A. M.; and Santos, P. R. dos. 1991. Ash-fall derived vitroclastic tuffaceous sediments in the Permian of the Paraná Basin and their provenance. In Ulbrich, H. H. G. J., and Rocha-Campos, A. C., eds. Gondwana Seven: Proceedings of the Seventh International Gondwana Symposium. São Paulo, Instituto de Geociências, Universidade de São Paulo, p. 147-160.

Crowell, J. C. 1999. Pre-Mesozoic ice ages: their bearing on understanding the climate system. Geol. Soc. Am. Mem. 192, 106 p.

Cumming, S. R., and Richards, J. R. 1975. Ore lead isotope ratios in a continuously changing Earth. Earth Planet. Sci. Lett. 28:155-171.

Daemon, R. F., and Quadros, L. P. 1970. Bioestratigrafia do Neopaleozóico da Bacia do Paraná. In Congresso Brasileiro de Geologia, 24th (Brasília), Ann., p. 359-412.

de Santa Ana, H. B.; Goso, C.; and Daners, G. 2006. Cuenca Norte: estratigrafia del Carbonífero-Pérmico. In Veroslavsky, G.; Ubilla, M.; and Artines, S., eds. Cuencas sedimentarias de Uruguay: geología, paleontología y recursos naturales: Paleozoico. Montevideo, Uruguay, DIRAC (División Relaciones y Actividades Culturales), p. 147-208.

Eyles, C. H.; Eyles, N.; and França, A. B. 1993. Glaciation and tectonics in an active intracratonic basin: the late Palaeozoic Itararé Group, Paraná Basin, Brazil. Sedimentology 40:1-25.

Fabris de Matos, S. L.; Yamamoto, J. K.; Hachiro, J.; and Coimbra, A. M. 2000. Tonsteins da Formação Rio Bonito no depósito de carvão Candiota, RS. Rev. Bras. Geocienc. 30(4):679-684. 
Fabris de Matos, S. L.; Yamamoto, J. K.; Riccomini, C.; Hachiro, J.; and Tassinari, C. C. G. 2001. Absolute dating of Permian ash-fall in the Rio Bonito Formation, Paraná Basin, Brazil. Gondwana Res. 4(3):421426.

Farjallat, J. E. S. 1970. Diamictitos neopaleozóicos e sedimentos associados do sul de Mato Grosso. Bol. Div. Geol. Mineral. 250. Brasília, Departamento Nacional de Produção Mineral, 32 p.

Fernandes, M. T. 2007. Ocorrências de material vulcanoclástico na Formação Corumbataí (Neopaleozóico), Bacia do Paraná. São Paulo, Instituto de Geociências da Universidade de São Paulo, 39 p.

Frakes, L. A., and Crowell, J. C. 1969. Late Paleozoic glaciations: I, South America. Geol. Soc. Am. Bull. 80:1007-1042.

França, A. B. 1994. Itararé Group: Gondwanan Carboniferous-Permian of the Paraná Basin, Brazil. In Deynoux, M.; Miller, J. M. G.; Domack, E. W.; Eyles, N.; Fairchild, I. J.; and Young, G. M., eds. Earth's glacial record. Cambridge, Cambridge University Press, p. 70-82.

Gesicki, A. I. D.; Boggiani, P. C.; Riccomini, C.; and Coimbra, A. M. 2002. Ice flow direction during the late Paleozoic glaciation in the Paraná Basin. I. S. Am. Earth Sci. 3:933-962.

Gordon, M., Jr. 1947. Classificação das formações Gondwânicas do Paraná, Santa Catarina e Rio Grande do Sul. Notas Preliminares e Estudos, no. 38. Rio de Janeiro, Departamento Nacional de Produção Mineral, $20 \mathrm{p}$.

Guerra-Sommer, M.; Cazzulo-Klepzig, M.; Formoso, M. L. L.; Menegat, R.; and Mendonça Filho, J. G. M. 2008a. U-Pb dating of tonstein layers from a coal succession in the southern Paraná Basin (Brazil): a new geochronological approach. Gondwana Res. 14:474-482.

Guerra-Sommer, M.; Cazzulo-Klepzig, M.; Menegat, R.; Basei, M. A. S.; Barbosa, E. G.; and Simas, M. W. 2008 b. Geochronological data from the Faxinal coal succession in southern Paraná Basin: a preliminary approach combining radiometric $\mathrm{U}-\mathrm{Pb}$ age and palynostratigraphy. I. S. Am. Earth Sci. 25:246-256.

Guerra-Sommer, M.; Cazzulo-Klepzig, M.; Santos, J. O. S.; Hartmann, L. A.; Ketzer, J. M.; and Formoso, M. L. L. 2008c. Radiometric age determination of tonsteins and stratigraphic constraints for the lower Permian coal succession in southern Paraná Basin, Brazil. Int. I. Coal Geol. 74:13-27.

Guerra-Sommer, M.; Santos, J. O. S.; Cazzulo-Klepzig, M.; Hartmann, L. A.; Menegat, R.; and McNaughton, N. J. 2006. The geochronological significance of tonsteins in coal-bearing strata from the southern Paraná Basin, Brazil. South American Symposium on Isotope Geology, 5th (Punta del Este, Montevideo, Uruguay), Short Pap., p. 254-257.

Holz, M.; França, A. B.; Souza, P. A.; Iannuzzi, R.; and Rohn, R. 2010. A stratigraphic chart of the late Carboniferous/Permian succession of the eastern border of the Paraná Basin, Brazil, South America. I. S. Am. Earth Sci. 29:381-399.
Ludwig, K. R. 2001. Using Isoplot/Ex (version 2.4): a geochronological toolkit for Microsoft. Spec. Publ. 1. Berkeley, CA, Berkeley Geochronology Center, 54 p.

Martin, H. 1961. The hypothesis of continental drift in the light of recent advances of geological knowledge in Brazil and South West Africa. Alex L. du Toit Memorial Lecture 7. Trans. Geol. Soc. S. Afr. 64(annex):1-47.

Maynard, J. B.; Chocyk-Jaminski, M.; Gaines, R. R.; Krekeler, M. P.; Prokopenko, M.; Summers, A. M.; and Huff, W. D. 1996. Bentonites in the late Permian (Tatarian) Irati Formation of Brazil: geochemistry and potential for stratigraphic correlation. Geological Society of America Annual Meeting, 28th (Denver) Geol. Soc. Am. Abstr. Program 7:280.

Milani, E. J.; França, A. B.; and Schneider, R. L. 1994. Bacia do Paraná. Bol. Geocienc. Petrobras 8(1):69_ 72.

Milani, E. J.; Melo, J. H. G. de; Souza, P. A. de; Fernandes, L. A.; and França, A. B. 2007. Bacia do Paraná. Bol. Geocienc. Petrobras 15(2):265-288.

Mizusaki, A. M. P.; Formoso, M. L. L.; and Alves, D. B. 1999. Tephra layers in the southern portion of the South America continent. An. Acad. Bras. Cienc. 74:825-829.

Mori, A. L.; Souza, P. A. de; Marques, J. C.; and Lopes, R. da C. 2012. A new U-Pb zircon age dating and palynological data from the lower Permian section of the southernmost Paraná Basin, Brazil: biochronostratigraphical and geochronological implications for Gondwana correlations. Gondwana Res. 21:654-669.

Mundil, R.; Metcalfe, I.; Ludwig, K. R.; Renne, P. R.; Oberli, F.; and Nicoll, R. S. 2001. Timing of the Permian-Triassic biotic crisis: implications from new zircon $\mathrm{U} / \mathrm{Pb}$ age data (and their limitations). Earth Planet. Sci. Lett. 187:131-145.

Mune, S. E., and Bernardes-de-Oliveira, M. E. C. 2007. Paleofloristics and biostratigraphy of the Monte Mor (SP) tafoflora, subgroup Itararé, NE of the Paraná Basin. XX Congresso Brasileiro de Paleontologia (Búzios), p. 1-13 (In Portuguese).

Neregato, R.; Souza, P. A. de; and Rohn, R. 2008. Registros palinológicos inéditos nas formações Teresina e Rio do Rasto (Permiano, Grupo Passa Dois, Bacia do Paraná): implicações biocronoestratigráficas e paleoambientais. Pesqui. Geocienc. 35(2):9-21.

Passarelli, C. R.; Basei, M. A. S.; Siga, O., Jr.; Sato, K.; Sproesser, W. M.; and Loios, V. A. P. 2009. Dating minerals by ID-TIMS geochronology at times of in situ analysis: select case studies from the CPGeo-IGc-USP laboratory. An. Acad. Bras. Cienc. 81:13-97.

Piñeiro, G. 2006. Nuevos aportes a la paleontologia del Pérmico de Uruguay. In Veroslavsky, G.; Ubilla, M.; and Artines, S., eds. Cuencas sedimentarias de Uruguay: geología, paleontología y recursos naturales: Paleozoico. Montevideo, Uruguay, DIRAC (División Relaciones y Actividades Culturales), p. 257-280.

Rocha-Campos, A. C. 1967. The Tubarão Group in the Brazilian portion of Paraná Basin. In Bigarella, 
J. J.; Becker, R. D.; and Pinto, I. D., eds. Problems in Brazilian Gondwana geology. Curitiba, Instituto de Geologia, p. 27-102.

1970. Moluscos permianos da Formação Rio Bonito (Subgrupo Guatá), SC. Bol. Dep. Nac. Prod. Min. $251,88 \mathrm{p}$.

Rocha-Campos, A. C.; Basei, M. A. S.; Nutman, A. P.; Kleiman, L.; Varela, R.; Llambias, E.; Canile, F. M.; and Rosa, O. C. R. da. 2011. 30 million years of Permian volcanism recorded in the Choiyoi igneous Province (W Argentina) and their source for younger ash fall deposits in the Paraná Basin: SHRIMP U-Pb zircon geochronology evidence. Gondwana Res. 19:509-523.

Rocha-Campos, A. C.; Basei, M. A. S.; Nutman, A. P.; and Santos, P. R. dos. 2006. SHRIMP U-Pb zircon geochronological calibration of the late Paleozoic SuperSequence, Paraná Basin, Brazil. In South American Symposium on Isotope Geology, 5th (Punta del Este, Montevideo, Uruguay), Short Pap., p. 322-325.

2007. SHRIMP U-Pb zircon ages of the late $\mathrm{Pa}$ leozoic sedimentary sequence, Paraná Basin, Brazil. In Simpósio sobre Cronoestratigrafia da Bacia do Paraná (Búzios), Bol. Res., p. 33.

Rocha-Campos, A. C.; Santos, P. R. dos; and Canuto, J. R. 2008. Late Paleozoic glacial deposits of Brazil: Paraná Basin. In Fielding, C. R.; Frank, T. D.; and Isbell, I. L.. eds. Resolving the late Paleozoic Ice Age in time and space. Geol. Soc. Am. Spec. Pap. 441:97-114.

Rösler, O. 1978. The Brazilian Eogondwanic floral succession. Bol. Inst. Geocienc. Univ. Sao Paulo 9:85-91.

Santos, P. R. dos; Rocha-Campos, A. C.; and Canuto, J. R. 1996. Patterns of late Paleozoic deglaciation in the Paraná Basin, Brazil. Palaeogeogr. Palaeoclimatol. Palaeoecol. 125:165-184.

Santos, R. V.; Souza, P. A.; Alvarenga, C. J. S. de; Dantas, E. L.; Pimentel, M. M.; Oliveira, C. G. de; and Araujo, L. M. de. 2006. Shrimp U-Pb zircon dating and palynology of bentonitic layers from the Permian Irati Formation, Paraná Basin, Brazil. Gondwana Res. 9:456463.

Schneider, R. L.; Muhlmann, H.; Tommazi, E.; Medeiros, R. A.; Daemon, R.; and Nogueira, A. 1974. Revisão estratigráfica da Bacia do Paraná. Congresso Brasileiro de Geologia, 28th (Porto Alegre), Anais, p. 41-65.

Simas, M. W.; Guerra-Sommer, M.; Cazzulo-Klepzig, M.; Menegat, R.; Santos, J. O. S.; Ferreira, J. A.; and DeganiSchmidt, I. 2012. Geochronological correlation of the main coal interval in Brazilian lower Permian: radiometric dating of tonstein and calibration of biostratigraphic framework. I. S. Am. Earth Sci. 39:1-15.

Sircombe, K. N. 2000. Quantitative comparison of large data sets of geochronological data using multivariate analysis: a provenance study example from Australia. Geochim. Cosmochim. Acta 64:1593-1616.

Souza, P. A. 2006. Late Carboniferous palynostratigraphy of the Itararé Subgroup, northeastern Paraná Basin, Brazil. Rev. Palaeobot. Palvnol. 138:9-19.
Souza, P. A.; Félix, C. M.; Pérez-Aguilar, A.; and Petri, S. 2010. Pennsylvanian palynofloras from the Itu rhythmites (Itararé Subgroup, Paraná Basin) in São Paulo State, Brazil. Rev. Micropaleontol. 53:69-83.

Souza, P. A., and Marques-Toigo, M. 2005. Progress on the palynostratigraphy of the Permian strata of the Rio Grande do Sul State, Paraná Basin, Brazil. An. Acad. Bras. Cienc. 77:353-365.

Souza, P. A.; Vergel, M. M.; and Beri, A. 2007. Pennsylvanian and Permian palynostratigraphy of the Paraná/ Chacoparaná Basins in Brazil, Argentina and Uruguay: an integrative analysis. In Díaz-Martínez, E., and Rábano, I., eds. European Meeting on the Paleontology and Stratigraphy of Latin America, 4th (Madrid). Cuad. Mus. Geominer. 8:361-366.

Steiger, R. H., and Jäger, E. 1977. Subcommission on Geochronology: convention on use of decay constants in geo and cosmochronology. Earth Planet. Sci. Lett. 36:359-362.

Stern, R. A. 1998. High resolution SIMS determination of radiogenic trace-isotope ratios in minerals. In Cabri, L. J., and Vaughan, D. J., eds. Modern approaches to ore and environmental mineralogy. Short Courses, vol. 27. Ottawa, Mineralogical Association of Canada, p. 241268.

Veroslavsky, G.; Martinez, S.; and Ubilla, M. 2006. El Paleozoico. In Veroslavsky, G.; Ubilla, M.; and Martinez, S., eds. Cuencas sedimentarias de Uruguay: geología, paleontología y recursos naturales: Paleozoico. Montevideo, Uruguay, DIRAC (División Relaciones y Actividades Culturales), p. 11-36.

Viviani, J. B., and Rocha-Campos, A. C. 2002. Late Paleozoic exhumed glacial erosive landscape in Salto, estado de São Paulo. An. Acad. Bras. Cienc. 74:549550.

White, I. C. 1908. Relatório final da Comissão de Estudos das minas de Carvão de Pedra do Brasil. Rio de Janeiro, Departamento Nacional de Produção Mineral, $300 \mathrm{p}$.

Williams, I. S. 1998. U-Th-Pb geochronology by ion microprobe. In McKibben, M. A.; Shanks, W. C., III; and Ridley, W. I., eds. Applications of microanalytical techniques to understanding mineralizing processes. Rev. Econ. Geol. 7:1-35.

Zalán, P. V.; Wolff, S.; Conceição, J. C. J.; Astolfi, M. A. M.; Appi, V. T.; Zanotto, O.; and Marques, A. 1991. Tectonics and sedimentation of the Paraná Basin. In Ulbrich, H. H. G. J., and Rocha-Campos, A. C., eds. Seventh Gondwana Symposium (São Paulo), Proc., p. $83-117$.

Zalba, P. E.; Iñiguez Rodrigues, A. M.; Morosi, M.; and Maggi, J. 1993. Composición mineralógica, distribución y procedência de arcilas en secuencias carboníferas y pérmicas de Argentina, Bolívia y Uruguay. Douzième Congrès International de la Stratigraphie et Geologie du Carbonifère et Permien (Buenos Aires), C. R., 2:501-518. 